\title{
Cultural Ritual Turned Sex Tourism: The Case of the Larap Slambu Ritual at Mount Kemukus in Central Java
}

\section{Rahmi Setiawati}

Tourism Studies, Vocational Education Program, Universitas Indonesia

\section{Abstract}

This study seeks to understand the Larap Slambu cultural event as a cultural tourist attraction at Mount Kemukus while exploring its rituals routed in the mixed concepts of belief, religion and myth prevalent in ancient Javanese communities referred to as Kejowen. A ritual as a habitual action contains transcendental values. Thus, rituals associated with voluntary performances by a community can be hereditary and characterized by a patterned behavior. This study uses a qualitative approach with the

Corresponding Author: Rahmi Setiawati rahmisetyawati@yahoo.com

Received: 8 June 2018 Accepted: 17 July 2018 Published: 8 August 2018

Publishing services provided by Knowledge $\mathrm{E}$

(c) Rahmi Setiawati. This article is distributed under the terms of the Creative Commons

Attribution License, which permits unrestricted use and redistribution provided that the original author and source are credited.

Selection and Peer-review under the responsibility of the $2 n d$ ICVHE Conference Committee.

\section{G OPEN ACCESS} interpretive paradigm of ethnography method of communication. The findings reveal that the Larap Slambu, as a ritual commemorating the Javanese New Year (Malam Suro), is being used as a cultural tourism attraction featuring rituals in commemoration of Prince Samudro, an ancient Javanese prince, at his tomb and through puppet shows. Rituals performed are determined by a belief system adhered to by each ritual participant. Larap Slambu rituals can build social solidarity and togetherness through the 'slamaton' event, a form of gratitude for the blessings that have been received by ritual participants. Over the recent years, with an increase of tourists to the cultural site, sex rituals feature more.

Keywords: ritual communication, communication ethnography, Larap Slambu, cultural attraction

\section{Introduction}

The pilgrimage ritual of Larap Slambu is one of the ritual forms of cultural attraction packaged by the Saragen Department of Tourism and Sports as a cultural tourism attraction, which consists of a series of rituals and ceremonial processes of traditional and religious activities. These activities have a cultural appeal because of the unique historical background of Java as depicted in form of artifacts, sites, dances and art, as well as other activities. The cultural diversity and religion within these activities are able to attract tourists or visitors to witness the rituals. 
These rituals are held during the month of Syuro, every first month of the Javanese calendar and coinciding with the Islamic month of Muharram. Wayang kulit, a puppet show is staged every Thursday night, while on the Thursday the first week, the slambu tradition - a cloth wash to cover the tomb of prince Samoedro. Larap slambu is believed to be a blessing for visitors who participate in the laundry.

The ritual process is a series of communication activities consisting of the situation or context of the occurrence of communication, the sequence and the events. In this research will analyze activities, competence and component relationships, including language as a tool in the ritual communications that produce a ritual communication pattern known as Larap Slambu.

However, there has been a change in the Larap Slambu ritual, at the time of the ritual, the pilgrimage ceremony of Ngalap Berkah, is a complement to the cultural ritual. Ritual behavior in the Ngalap Berkah, ceremony which is supposed to bring blessings to pilgrims has now undergone change in process and has now turned into a prostitution ritual around the tomb of Prince Samudera, who is the character of the larap slambu ritual. This study makes it interesting to study, because since the 1980s, Mount Kemukus is a tourist area legally established by Sragen regency. The stewardship of the Ngalap ceremony was previously managed by local villagers but was taken over by the tourism office. Changes in management of the ceremony's stewards encouraged commodification. The expansion of tourism and prostitution led to the ritual of 'working on slambu' coupled with the 'ngalap blessing', ritual which further reinforces the view of 'sex ritual' as part of the blessing of blessing.

Referring to Foucault (2000) who has a view that sex as part of sexuality which is a social construction, the ritualistic conduct of a sex pilgrimage on Mount Kemukus can be viewed as a cultural product that is actualized by the individuals involved. This view is seen from the presence of Commercial Sex Actors (PSK) since the 1980 s who are rationally motivated by economic insistence. Some of the PSK are originally migrants who have settled and lived as permanent residents in Pendem Village. In other words, the proliferation of prostitution is not only caused by sex ritual, but also driven by the development of tourism that has greatly increased since the 1980s (Seodhha, 2013: 108).

Furthermore, the news by Patrick Abboud of the Australian SBS Dateline program in 2014 on sex ritual offenders, ranging from married men, housewives, officials, to commercial sex workers (PSK) emphasizes the dynamic nature of ritual behavior of the pilgrimage of Mount Kemukus as a pilgrimage ritual sex. Mount Kemukus is the site of the tomb of Prince Samudro and became a tourist destination for local tourists 
and a local government revenue source through the admission ticket fees to the tourist site but its popularity as also a place of prostitution raises a problem. The complexity of the problem can be seen from Abboud's observation that the local government and religious leaders seem to let prostitution impersonate rituals on Mount Kemukus, as well as the vulnerability of the spread of venereal diseases. In response to Abboud's observations, the Government of Sragen regency, Central Java began to curb the existence of lodging and karaoke clubs around the pilgrimage areas. Other localities around Mount Kemukus like Pendem Village, Sumber Lawang Sub-district, and Sragen have seen prohibition operations that cracked down a total of 69 karaoke clubs and 158 PSK venues, however, the response of the local government caused the number of visitors to Gunung Kemukus attractions to decrease; from 60 thousand in 2013 to 52 thousand in 2014 in Pendem village, Sumberlawang District is about 60 thousand, then the year 2014 and only about 52 thousand only. This led to a change in the pilgrimage rituals to be dominated more by the rituals of Ngalap Berkah, so that the tourist attraction to the culture now shifts to sex tourism attraction.

\section{Research Focus}

Efforts to understand diversity of behavior patterns cannot be separated from understanding the socio-cultural life in the village community of Pendem in Sragen district so the use of communication ethnography plays a role in the study of events and communication at Mount Kemukus. So, the ritual communication of larap slambu, becomes a point of study in tourism, that is also in a form of a cultural tourism attraction. Therefore, the focus of this research is: understanding 'the Larap Slambu ritual as a cultural tourist attraction in Mount Kemukus in the Sragen regency of Central Java in Indonesia'.

\section{Literature Review}

The Meaning of Ritual in a Communication Perspective:

Mulyana (2005: 25) believes that ritual communication is related to expressive communication that is usually done collectively. Rituals include the use of behavioral models that express social relationships; words or behaviors that are symbolic. Ritual actors participate in ritual communication to reaffirm their commitment to family, ethnicity, nation, state, ideology or religious tradition. Meanwhile, Rothenbuhler (1998: 28) in Couldry (2005: 60) understood a ritual as a habitual action that may be hereditary, 
formal and containing transcendental values. Mulyana and Rothenbuhler views generally understand the rituals associated with voluntary performances by the community for generations (based on custom) concerning patterned behavior. The show aims to symbolize the influence in the life of society. Furthermore, a ritual is one way of communicating. All forms of rituals are communicative. A ritual is always a symbolic behavior in social situations, so a ritual is always a way of conveying something. Ritual understanding as one of the ways of communicating rises the term of ritual communication which was first proposed by James W. Carey. Carey (1992: 18) who explains:

In a ritual definition, communication is linked to terms such as 'sharing', 'participation', 'association', 'fellowship', and 'the possession of a common faith'

Carey's opinion means that communication related to sharing, participation, association, friendship, and ownership of the same faith. Furthermore, Carey is of the view that communication is not directly directed to disseminate messages in a space, but rather to the maintenance of a community in a time while in ritual. Communication is not built as an action to provide information, but to represent shared beliefs.

His views play a role in understanding communication as a process through which a common culture is created, altered and replaced. Ritual communication is not directly intended to disseminate information or influence, but to create, re-create, and celebrate shared beliefs. Meanwhile, McQuail's (2000: 54) understanding of ritual communication also called expressive communication means that communication in the ritual communication model emphasizes the intrinsic satisfaction of the sender or recipient rather than the other instrumental goals. Ritual or expressive communication depends on mutual emotion and understanding.

Meanwhile, Hammad (2006: 3), explains that in understanding ritual communication, there are some notable features, like its being closely related to sharing, participating, gathering, friendliness to a community with the same belief. In the pilgrimage ritual ngalap berkah in the Tomb of Prince Samudro is a form of ritual communication that is done by sharing, participation, gathering and friendship among fellow pilgrims, caretakers and communities around the location of the tomb and business actors. Each ritual is a form of communication not directly intended for the transmission of messages, but to maintain the integrity of the community, so an important part of ritual communication is the continuity or sustainability of the ritual, in this study it is the pilgrim. In addition, communications built are also not directly to convey information but to represent or re-create the common beliefs of society. Thus, the communication 
pattern that is built is like a sacred ceremony where everyone is gathered together (e.g., performing prayers together, singing and other ceremonial activities). In this a joint prayer is led by the caretaker, the same is with funeral ritual ceremonies, this can be in form of singing, reciting prayers and other forms of ceremonial activity.

\subsection{Language in ritual communication}

Humans communicate with the language, either through verbal messages (oral and written) as well as non-verbal messages. The advantage or communication lies in the way humans use language as a means of communication, and the use of symbols. The representation of symbols allows humans to name something previously projected from the external environment (Liliweri, 2011, 350-351). Furthermore, language is the most verbal symbol and is most often used in the communication process. Language can also be defined as a set of symbols with rules combining symbols used and understood by a community (Mulyana, 2007: 260). The verbal and non-verbal language of the social system is a means of sharing experiences among members of the social system, as expressed by Porter, Samovar, and Cain (1985: 134):

Any verbal or non-verbal language uses symbols that stand for or represent various concrete and abstract parts of our individual realities, these symbols in turn are governed by rules that tell us how to use them in order to best represent our experiences

The language concept used in this research is the language as a reflective and structured symbol system that is used to classify objects, events, and relationships in the world, 'language is a potentially self-reflexive, structured system of symbols which catalog objects, events, and relations in the world (De Vito, 1970 in Bustan, 2010: 3). De Vito's opinion shows that language is a system of meaningful human symbols to reflect the view of the world, both factual and symbolic that the existence of reference object is imaginative.

\subsection{Javanese religion}

Subagya (1976: 22) views the belief of some of the Javanese society as the supernatural essence of their lives. Although some Javanese are adherents to Islam, Catholicism, or Hinduism, some still hold the original beliefs of their ancestors (Kejawen). Koentjaraningrat (1984: 312) states it as a form of Javanese Islamic religion (Jawi religion) or Kejawen as a set of beliefs and concepts of Hindu Buddhism that tends toward 
the mysticism which is mixed into one and is recognized as some form of Islam. The religious system generally consists of a balanced integration between the elements of animism, Hinduism, and Islam (syncretism) which is reflected in the people's tradition. Understanding of superstition, spirits, ancestral spirits existed in some Javanese societies, but still recognizes God as the supreme ruler in cosmology. God in Javanese society has various names, for example: 'Gusti Kang Maha Agung', 'Gusti Kang Maho Luhur', 'Gusti Kang Murbeng Dumadi', 'Hyang Wenang', 'Hyang Tunggal', and so on, while acknowledging prophets as God's messengers.

\subsection{Cultural tourism}

Understanding cultural tourism according to Geriya (1995: 103) is one type of tourism that relies on cultural potential as the most dominant attraction as well as providing identity for the development of tourism. In tourism activities there are ten cultural elements that become tourist attraction they are: (1) craft, (2) tradition, (3) history of a place/area, (4) architecture, (5) local food, (6) art and music, (7) The way of life of a society, (8) religion, (9) language, (10) local traditional clothing (Shaw and William, 1997). These cultural elements seem to be highly relevant to the kind of tourism developed in Bali, cultural tourism. Cultural tourism is an activity that allows tourists to know and gain experience about the different ways of life of others, reflecting on their customs, religious traditions and intellectual ideas embodied in the unknown heritage (Borley 1996: 181). Sirtha (2001) put forward cultural tourism motivation, among others as: (1) encouraging the utilization of regional and national production; (2) maintaining cultural values, norms, customs and religions; (3) environmentally sound, both to the natural and social environment (Arismayanti, 2006).Top of Form

\subsection{Methodology}

The study uses the method of Ethnography Communications holistically, because it covers various aspects and their relationships. The ethnography of communication differs from linguistic and sociolinguistic anthropology, because ethnography of communication focuses its study on communication behaviors involving language and culture ([17]: 17). Culture is 'learned behavior' and a 'mental phenomenon' (Greetz, 1974). Communication is a tool for learning and manifesting mentally in the form of symbols. Cultural analysis enters communications research in maintained systems or forces against certain subjects, because culture is a set of activities, a picture of lifestyles, 
the process by which reality is built, maintained and transpired ([31]: 246). Originally, ethnography of communication is the ethnography of speech. The ethnography of communication is applied to a language or community group, so that language usage in speech or broader language communication can be applied.

\subsection{Stages of ethnographic communication research}

Hymes put forward the stages of conducting ethnographic communication research in a speech society, through the following explanation:

As a first step to describe and analyze an existing communication pattern in a society, is to identify the events of communication that occur repeatedly. The next step is to inventory the components that build the communication event, and then find the relationship between the components.

Therefore, the research stages in the ethnography of communication in this study are:

1. Identify recurrent events.

2. Inventory communication components that build such recurring communication events.

3. Find the relationship between communication components that build communications events, which will be known later as communication patterning.

\subsection{Findings and discussion}

In addition to rituals of pilgrimage there are other rituals performed at the tomb of Prince Samudro, Larap Slambu which is held once a year in the Javanese in the month of Syuro or Islamic month of Muharram. Larap Slambu also involves a ceremonial washing of the cover cloth of Prince Samodro's Tomb. The purpose of this ceremony is to purify Prince Samodro's grave and replace some of the curtains. The Larap Slambu ceremony is a program of the Sragen district Tourism Office in increasing the regional budget revenue, so the event is packaged to create attraction for foreign tourists because of its uniqueness, but for domestic tourists many of them who dominate the ceremony seek blessing through their belief in the attributes of the figure of Prince Samudro who is considered a powerful figure. The role of the Tourism Office in preparing the ritual is evident in the Picture $B$, the entrance to the ritual ceremony site. 
The larop slambu ceremony is typically held for 2 days, and on the eve of the ceremony, pilgrims hold vigil at the tomb of Prince Samudro until around midnight, thereafter most pilgrims do not sleep but continue with rituals at the tomb praying and reciting religious incantations, with the aim of obtaining blessings from Samudro.However, there is also a larap slambu event dominated with liquor and beer drinking in stalls holding Karaoke entertainment and peddling prostitutes, as revelers celebrate the turn of the Javanese year, ushering in the Javanese New Year. This particular event is one that raises the negative image about Mount Kemukus, in some media reports it has been referred to as 'sex-mountain'. Ironically this kind of portrayal is also a kind of attraction of some visitors to Mount Kemukus as sex tourists, in addition to pilgrimage. Thus, business minded business people like some shopkeepers, karaoke bar operators also facilitate and operate prostitution activities around the pilgrimage site. Furthermore, many pilgrims come with the belief that performing sexual intercourse at the confines of the tomb of Prince Samudro, is a complement in the pilgrimage ritual and instrumental in attaining full the full blessings of ngalap.

It is worth noting that typically the situation at the tomb of Prince Samudro on the eve of the larap slambu is rather chaotic, vibrant, and contradictory and rather interesting depending on one's view. Some pilgrims perform a variety of activities; in the form of humble demonstration of devotion and remembrance, others perform what can utterly be perceived as outrageous negative actions. In the midst of all these activities is also the display of Javanese cultural gear and performances in form of ornaments, artifacts, textile performances and many other impressively visual displays and performances. The general situation of this pilgrimage and the ceremonies therein present a variety of cultural and social experiences which formulate themselves into a powerful cultural and tourist attraction for both local, national and foreign tourists.

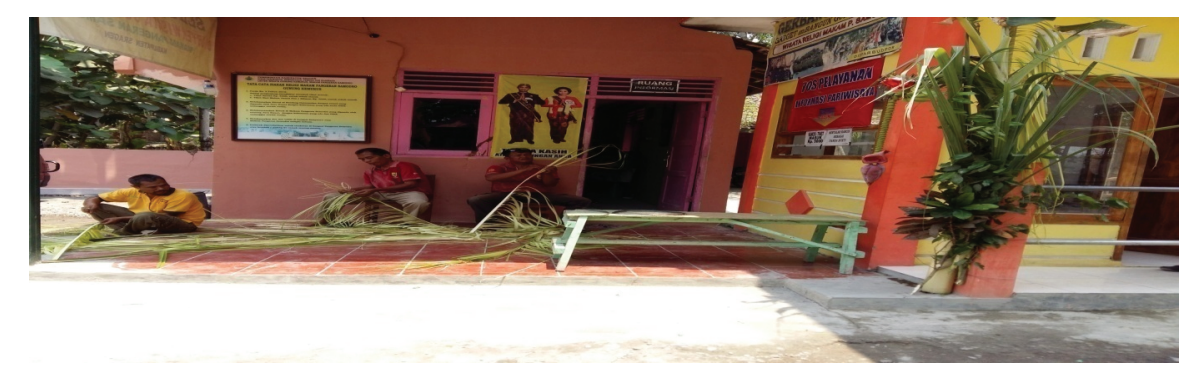

Figure 1: Tourism and community office staff preparing for the Larap slambu ceremony. 


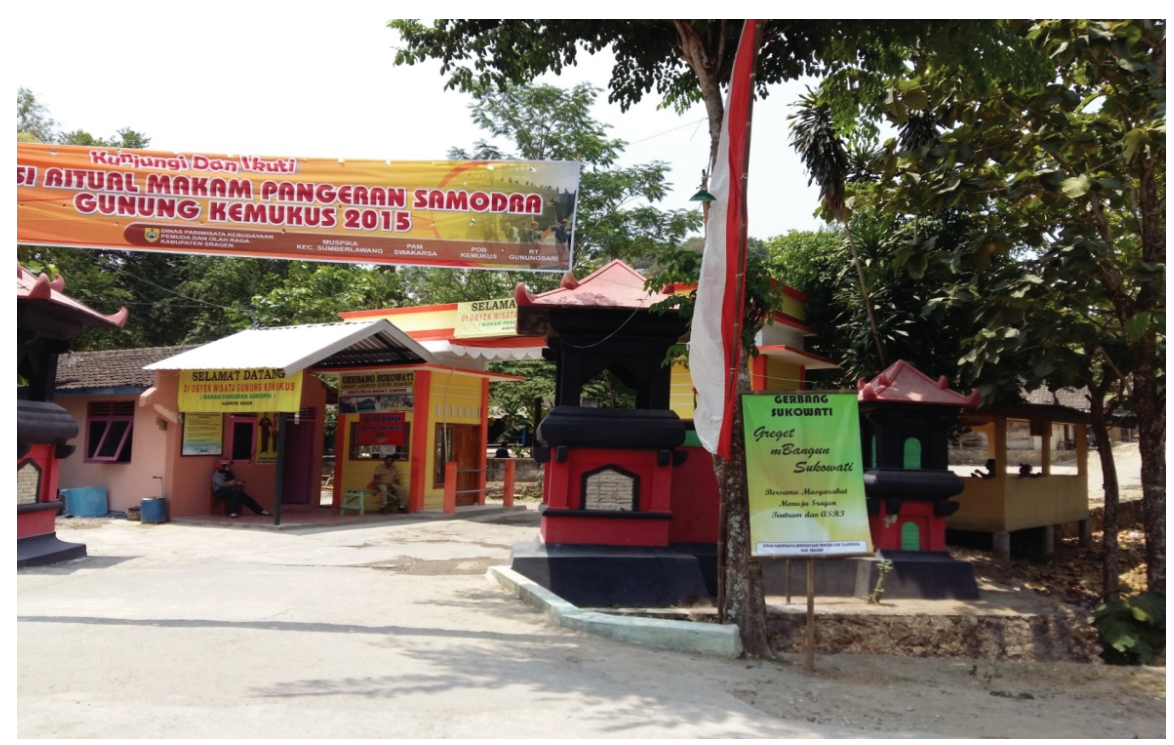

Figure 2: Entrance or welcome greeting to the guests at Larap Slambu ceremony. (Source: Rahmi, 2015).

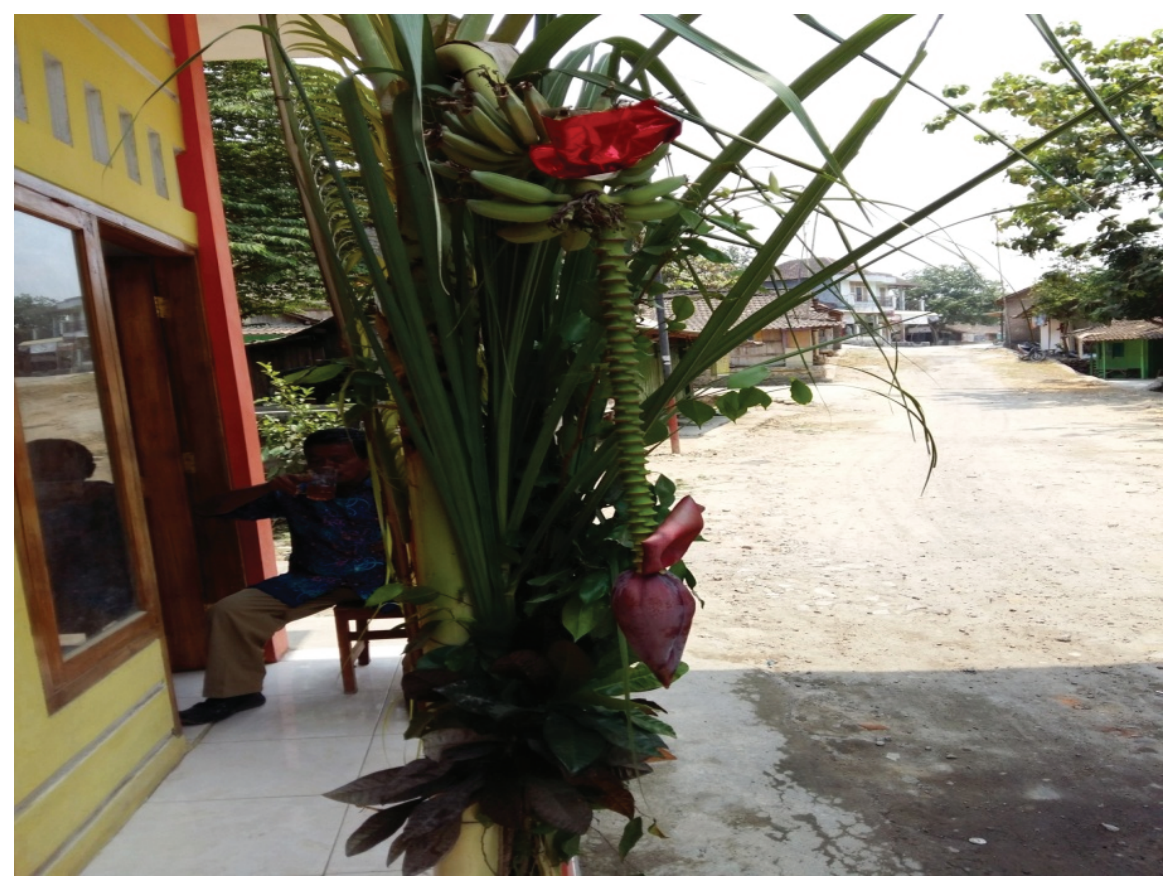

Figure 3: Umbul-Umbul entrance to the grave site of Prince Samudro. (Source: Rahmi, 2015).

\subsection{Communication events}

The Larap Slambu event is a ritual formed by the Sragen district local government, to attract visitors to the Tomb of Prince Samudro, at mount Kemukus by officially designating the site as a tourist destination. Therefore, the management of Mt. Kemukus is given to three institutions, namely the District, the Department of Tourism and the Police. Tourism has become part the development initiative in the area that provides 
welfare to the people with the embodiment of the sustainability concept and involvement of the local society to bolster of tourism industry in the area.

The tourism potential of Larap Slambu is well perceived by the local government of Sregen district which manages tourism activities through the Department of Tourism, Culture, Youth and Sports. During the rituals of Larap Slambu, high ranking local government officials also participate and closely follow the rituals dressed in traditional Javanese attire. On that day tourists, can find ornaments and traditional Javanese clothes, display of traditional soldiers with traditional weapons typical of the ancient era. The traditional feel of Java is felt in Larap Slambu's rituals. It is interesting to observe the pattern of life, culture, and belief that goes on in the community of Mount Kemukus region. The event also displays a mixture of traditions from Hindu native Javanese and Islamic culture; complete with historic legends and artifacts.

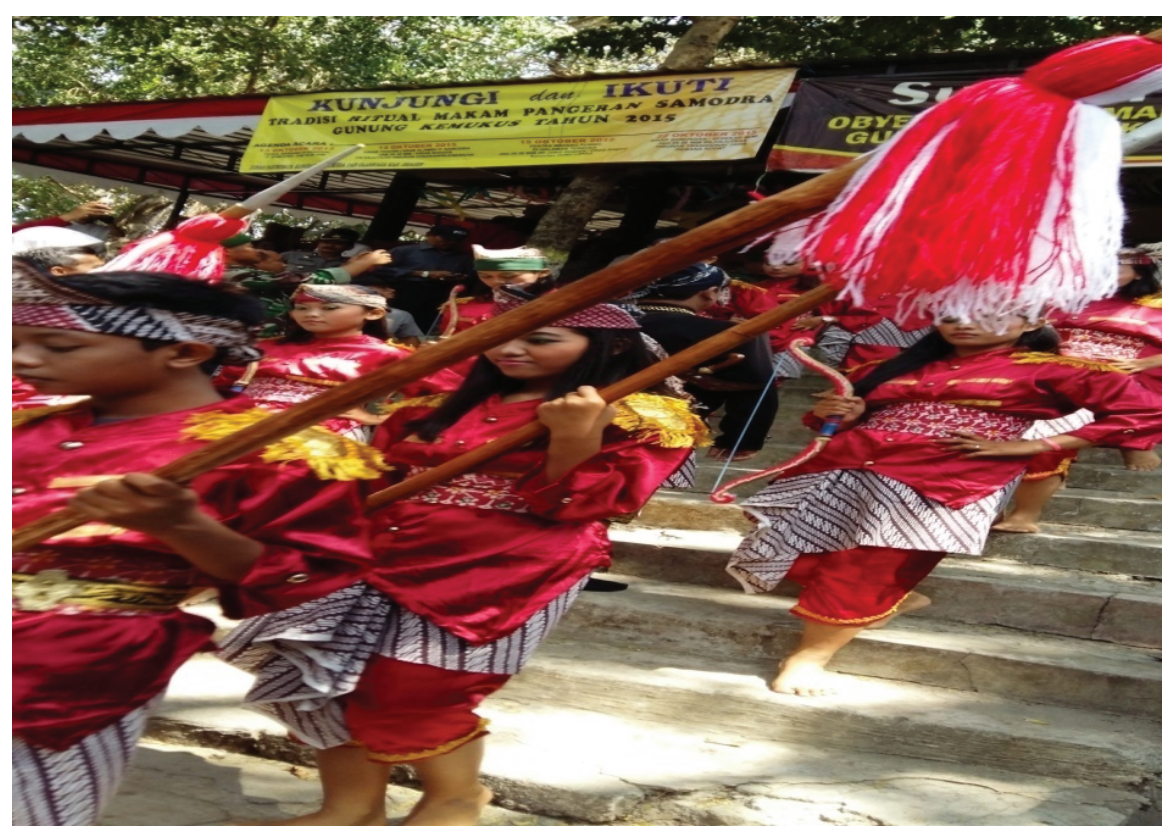

Figure 4: Traditional soldiers' costume display by young Pendem villagers. (Source: Rahmi, 2015).

\subsection{Communicative action}

Activities in the Nglap Slambu event are communicative. The ritual of purification of Prince Samudro's cover tomb cloth is usually held from the morning at $7 \mathrm{am}$. At that time many residents who have come from various regions are crowded at the activity location. The rituals begin with ushering water flowers, slambu, and mori cloth and someubo rampe as offerings to the flowing river that empties into Kedung Ombo Reservoir located east of the tomb. The distance of the location is approximately 500 


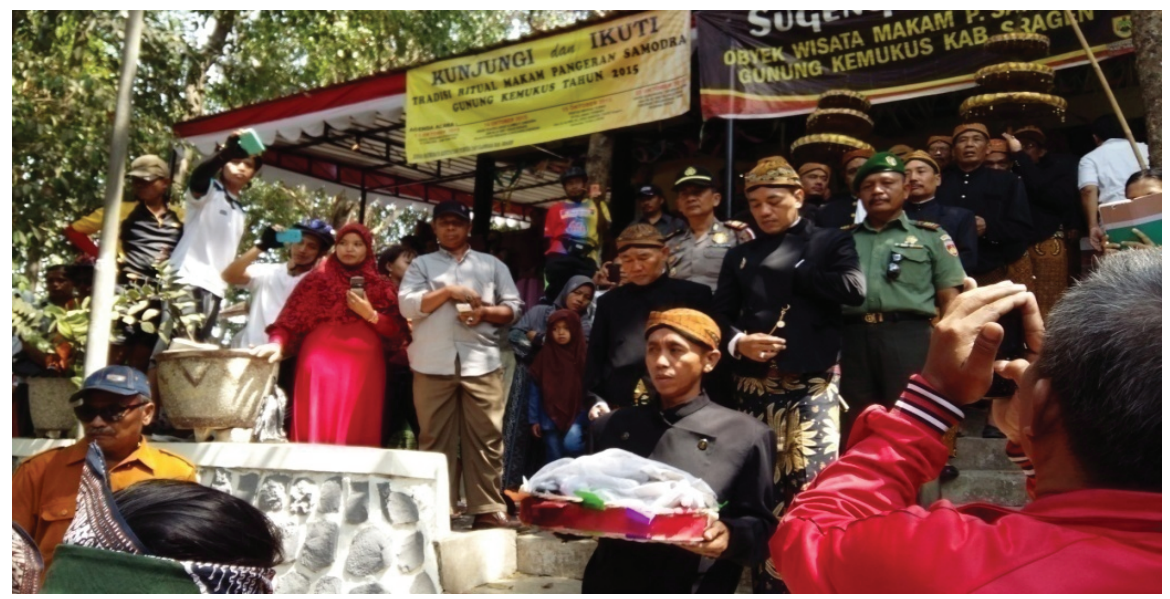

Figure 5: Ushering of the mosquito net by local government officials and caretakers. (Source: Rahmi, 2015).

meters and by walking down the stairs, the carrier group escorted by a parade of actors in traditional soldiers' costumes. All parties involved in the event fully dress in Javanese clothing and fashions, including honorary guests such as the district local government leader (Bupati). The process of the ceremony starts at the main building of Prince Samodro's Tomb with a neatly folded mosquito net. After reciting a prayer, the mosquito net is taken to the same river flowing to Kedung Ombo dam separating Pendem village from Mount Kemukus. On the way to this river, the mosquito nets are escorted by about 20 traditional guards with spears in traditional soldier costume and 20 archers. It is also followed by a troupe of tambourine players and singers of traditional religious songs.

Once descended from the main building of the tomb, the procession is accompanied by song traditional religious songs like Qosidah and Rebana, on arrival the mosquito net where it is washed and rinsed. A set of gamelan and Janur musical instruments adorn the place of washing rinse the mosquito net. Before rinsing the net in a large plastic barrel, there is a speech from the Local government leader and the reading of the history of Mount Kemukus from a historian and a greeting from the tourist site caretaker. At this juncture officers of the district Department of Tourism takes the opportunity to address the gathering and air out the events pros and cons and encourage the community to use the event as a means of tourism promotion to attract tourists.

After the scramble for water, people move upward, to the porch of the tomb, register and wait their turn to receive a piece of torn white curtain Slambu to be distributed to those who want including tourists. The torn pieces of curtain are distributed in envelopes symbolize of receiving blessings. Interest in receiving slambu is expressed by registration in which is used to call out the names of those registered to move over 


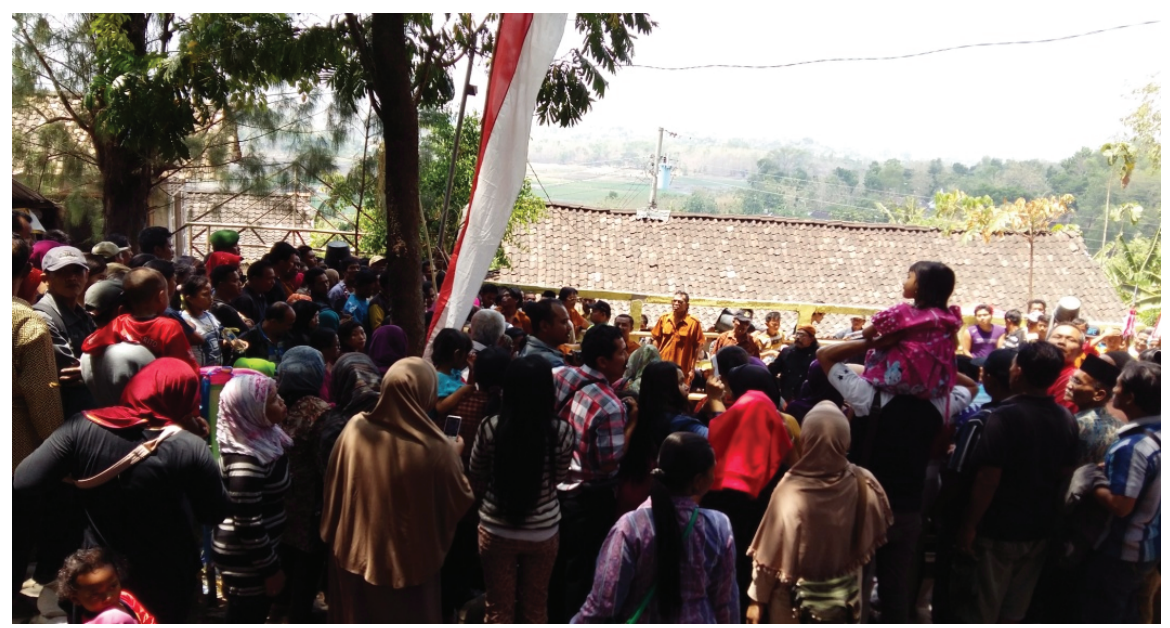

Figure 6: Visitors gather to take water that is believed to bring blessings. (Source: Rahmi, 2015).

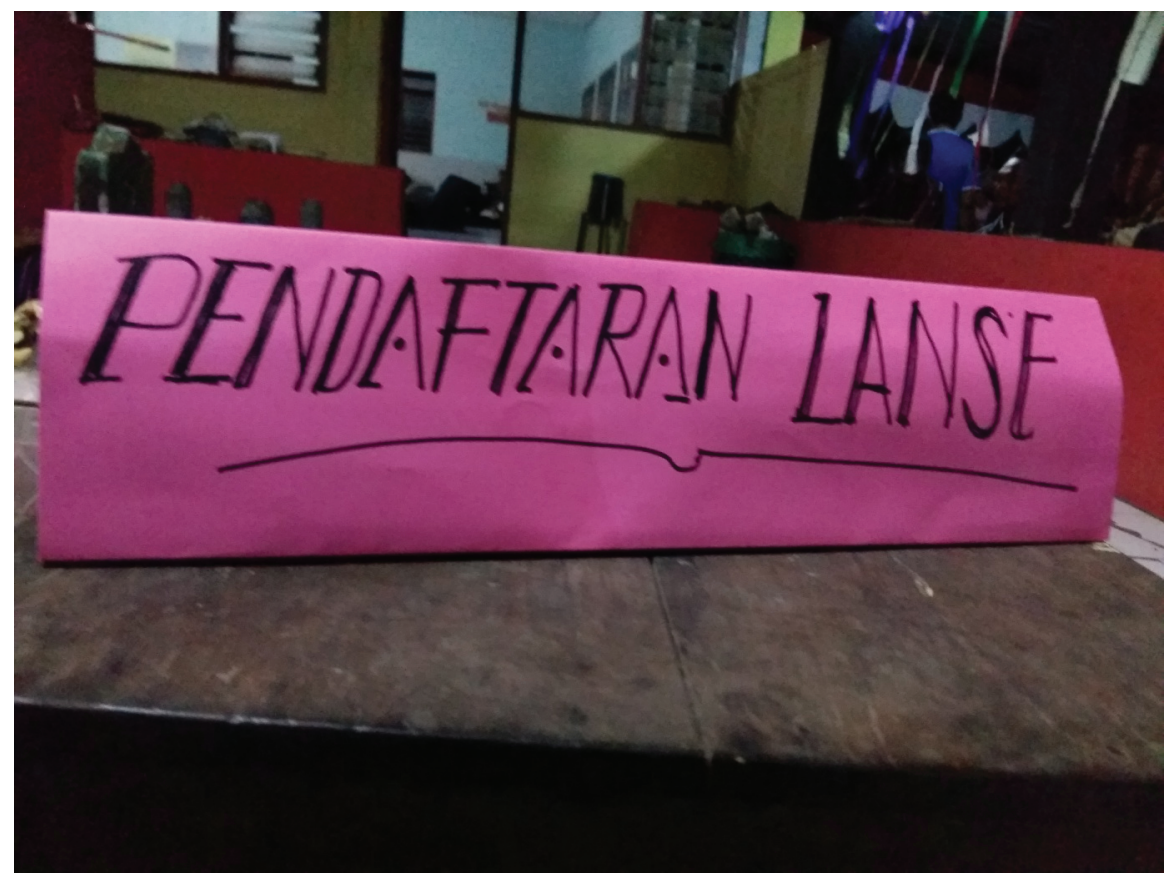

Figure 7: Registration point at the tomb of Prince Samudro. (Source: Rahmi, 2015).

and receive hand money to the tomb care taker and to receive the piece of torn white curtain.

What is interesting is that some people believe that the flowers that fall from the top of the tomb are considered to bring blessings. As was believed and done by Ms. Sarikem, the following image shows seven flowers she took after they fell from the tomb décor believing they will bring her blessings, 'these flowers bring blessings, they can be used for bathing by mixing them into bathing water and taking a bath'. 


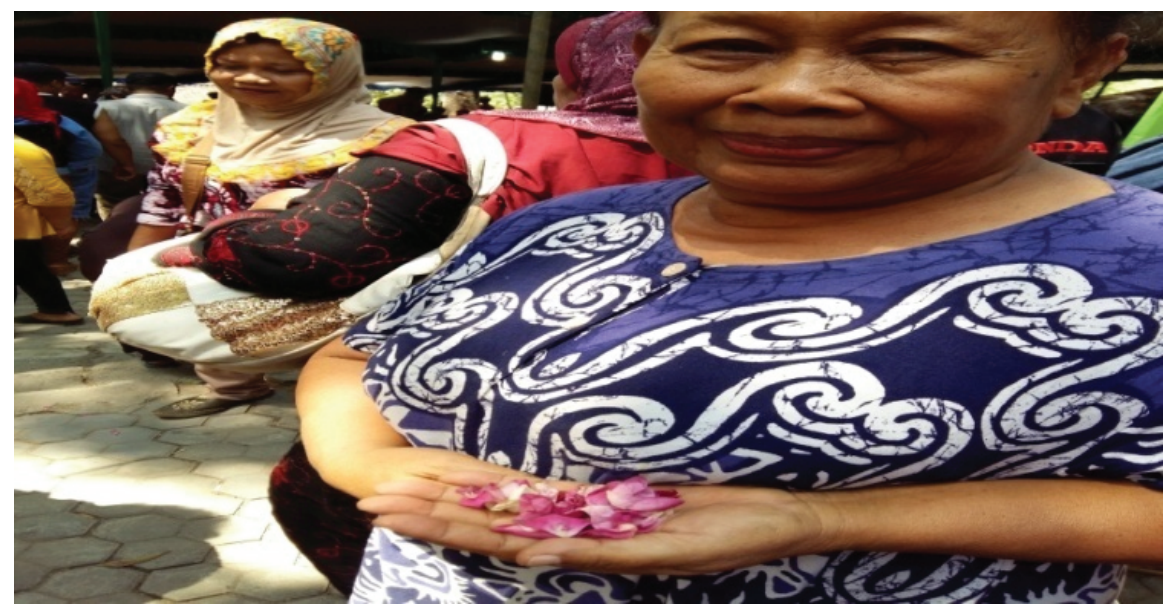

Figure 8: Photo of Mrs. Sarikem who has the belief that the flowers bring blessings. (Source: Rahmi, 2015).

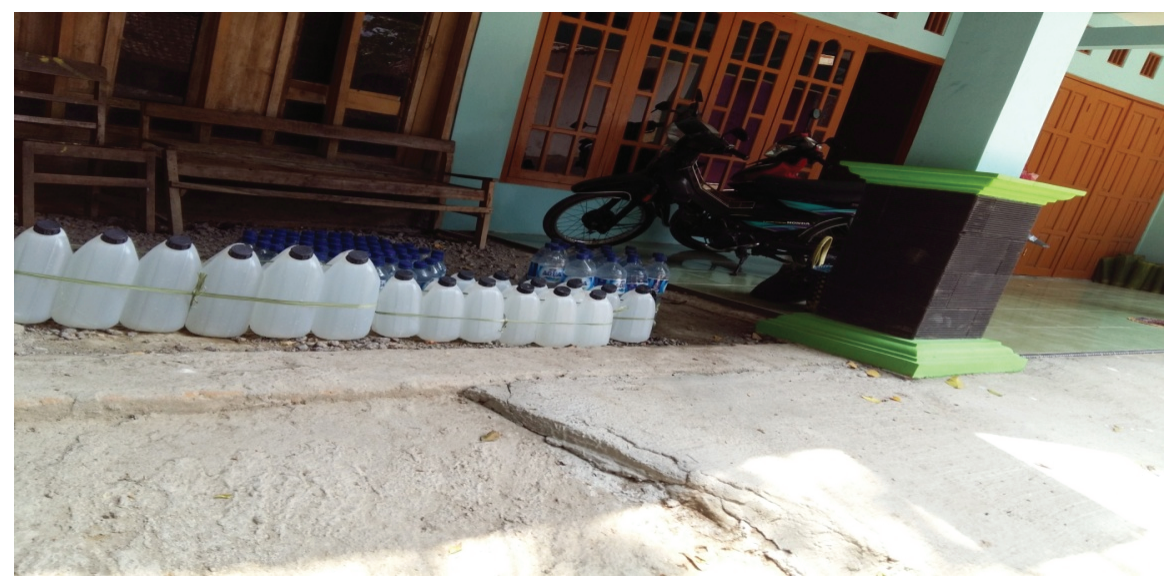

Figure 9: Water taken from Sendang Ontrowulan that is believed to bring blessings being sold to pilgrims. (Source: Rahmi, 2015).

\subsection{Wayang kulit performances}

This all-night shadow puppet show is performed at the closing of the month of Syuro, and is usually held on the eve of Friday Kliwon. The purpose of the puppet shows is to teach the audiences about the good, that to achieve success must be by working hard and earnestly or gradually. In addition, puppet shows are often held every year by the local government of Sragen's Department of Tourism and Transportation to enliven the month of Muharram/Syuro. In the Wayang Kulit show, slogans and messages are inserted about tourism development. This is done to invite the community to introduce Mount Kemukus as one of the tourist attractions in Sragen district. The Wayang Kulit show itself is very festive, it can be proved by the enthusiasm of the people watching it. Leather puppet performances contain moral education and behavior that can be used as role model. In the shadow puppet show, in fact has a lot of educative content delivered by the puppeteer through the character of a puppeteer in a story he 
plays. The story content generally depicts two characters, the good character and bad character.

The audience can take lessons from the story, especially about the appearance of the character of the puppets. Good character can be used as moral guidance and behavior, so that if exemplified and carried out in earnest will undoubtedly form human beings who have good character, virtuous and noble (sholeh and sholehah man). If one looks at and recognizes a wayang kulit show, then the person must assume that the shadow puppet show is entertainment. It is very reasonable, because they feel comforted both through the sound of musical instruments, their soothing sounds or the sound of the play characters and its story.

The wayang performance at the Larap Slambu ceremony tells the story of Semar Mbangun Kayangan. Is it true that Semar wants to build Kayangan inhabited by the gods? At this point we will be led to understand Semar's line of thought. And to understand it we need to know the cultural contestation in which this character is built on. Semar is a figure in the wayang depicting a Begawan, a figure of punakawan who advises Pandawa Knights as well as a symbol of the common people. Therefore he is considered in a character of a demigod.

One of the advantages of the puppet story is that it is still relevant even in the contemporary context. Lakar Semar mbangun may be used as a means to remind how the leader should run his government. The story is one with a constructive meaning. Perhaps leaders need to occasionally hear, learn, and imitate this story, because building a meaning can be defined as building a safe, peaceful, prosperous country starting from building up the personality of its leadership. For that it is necessary personal leaders to cling to 'kalimasada' or religious teachings, laws, and regulations that apply within the country. Be able to protect the people with 'kencana' umbrella which shade, protect, and serve, and to uphold the truth and fight against impermanence with the 'spear' of justice.

This kind of wayang story conveys messages containing positive values, that society must live harmoniously, fairly, work hard, and be able to control their emotions and lust. That wayang can still be used as a medium for people especially Javanese in conveying a message that instills certain values or a certain purpose.

\section{Discussion}

The location of the pilgrimage is not only thought to have the existence of spirits but also associated with former powerful figures that have visited there or resided there, 

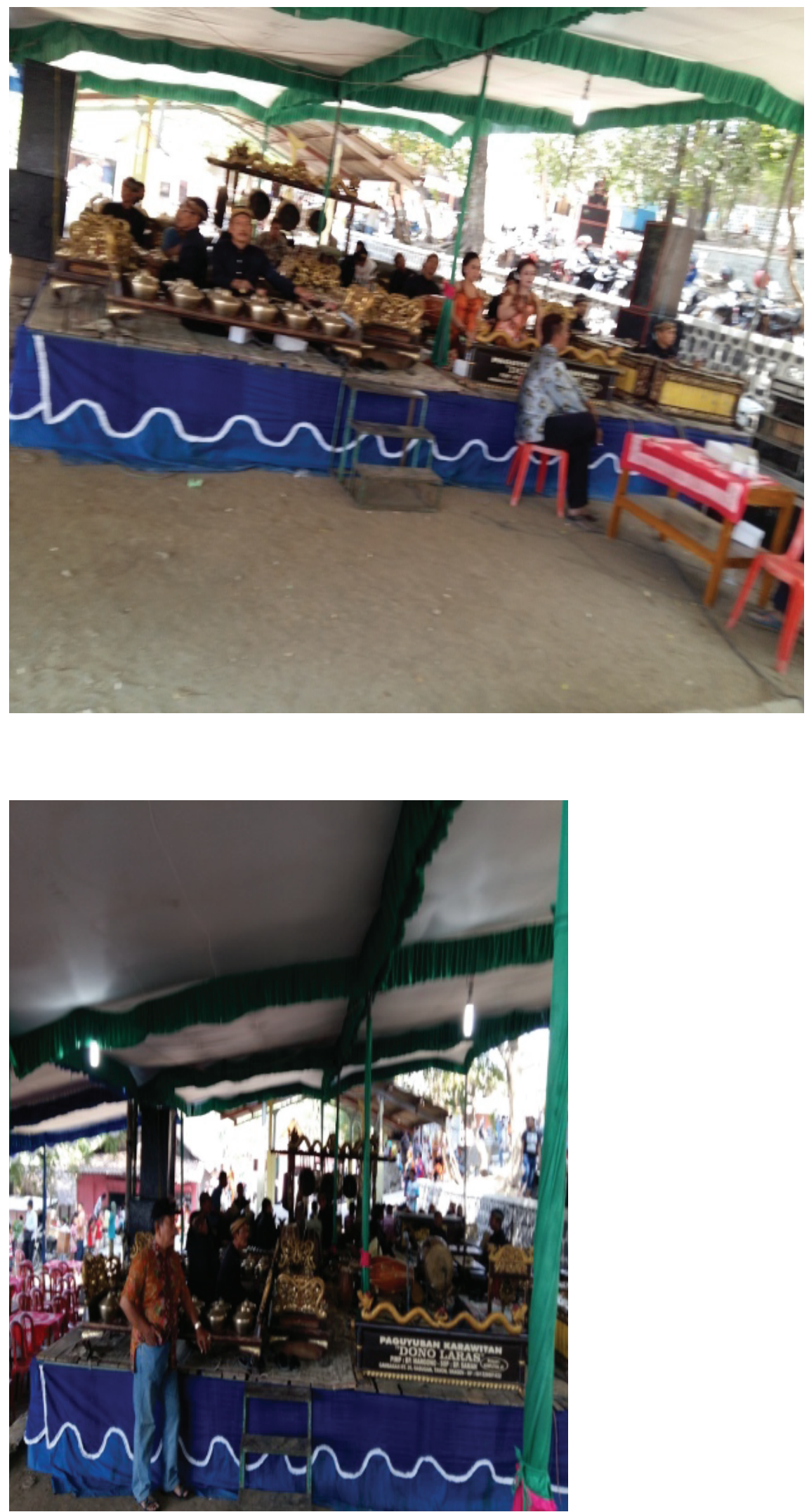

Figure 10: Preparation of a puppet show at the Larap Slambu ritual featuring gamelan musical instruments. (Source: Rahmi, 2015). 
TABle 1: Ritual Communication Component of Larap Slambu.

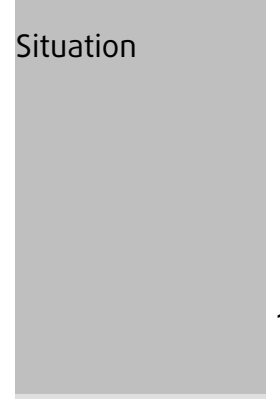

Participation

Purpose

Act Sequences

Key massages

Instrumentals

Norms

Genre
The Larap Slambu event is held at this location on a regular basis every $1^{\text {st }}$ day of the month of Syuro (Javanese calendar) or Muharram (Islamic Calendar) held as tradition of purifying the cover fabric of Prince Samudro's grave. The event is colored with Javanese culture, artifacts and ornaments from the Majapahit Kingdom and Surakarta Kraton, which is seen with their traditional Javanese dress, through traditional Javanese attire, soldiers with weapons in typical emulation of the ancient palace. The traditional feel of Java is felt in the Lorap Slambu ritual. This event is a trace of the encounter between the traditions of Hindu Javanese and Islam. Complete with various historic legends and artifacts.

Attended by the local government officials like the District Head, Village Head and other village units RT, RW and Community Leaders, Interlocker, PAM SWAKARSA as well as tourists and pilgrims who want to enjoy the cultural attractions, both domestic and foreign tourists whose motive or goal is to know the Javanese culture and local wisdom of Indonesian culture

The goal of Larap Selambu event is to clean the curtain which is the symbol of the cover of the tomb. Because its color is white, it must be cleaned every year. At the same time the goal is to cleanse themselves with objects that are considered sacred once a year, in what they call a 'night of syuro' and as a form of expression of gratitude for grace or fortune given from God Almighty or Allah S.W.T. Besides it is a means by which the regional government's increases tourism in Sragen regency through cultural tourism attractions by performing traditional javanese cultural rituals.

Provide information in the form of knowledge about Javanese culture and instilling the values of kindness with the philosophy of wayang figures through wayang shows entitled Semar Bangun Khayangan. In addition, the goal is to influence young people to love Javanese cultural arts.

The message conveyed shows a very sacred and formal situation, which shows the characteristics of Javanese culture in honoring a prominent person. Through gamelan music and puppet shows that are synonymous with Javanese culture.

Using the most upscale Javanese languages such as Javanese 'Kromo Ingggil', with Javanese music mix in the form of 'Sinden' and 'Rebana' with a mix of Arabic which shows its religious value to Javanese. A non-verbal media is used through the show from the beginning of the ritual cleansing of slambu until the end of the washing ritual at the river and in the puppet shows thereafter. The non-verbal form of messages using certain symbols in communication activities, such as the 7 flowers and water attributed to the Tomb of Prince Samudro.

The rules and procedures set or the arranged schedule of the rituals are arranged by the Department of Tourism and Culture of Sragen regency. Starting from the initial process of the release of the slambu or cover cloth of the Tomb of Prince Samudro, to the process of washing or cleansing (dijomes) to the installation of the cover of the tomb. Another norm in the pilgrimage on Mt. Kemukus, since the time of the ancestors is abstinence from anger, not following ones passions but surrender to prayer.

The story and the characters of Prince Samudro expressed by way of gamelan music and Rebana music shows the mixture of Islam and Hinduism, and inculcates the values of kindness with the philosophy of wayang figures in the form of messages through the Wayang Kulit shows. The use of the first verse of the Quran in the Slametan ritual is as a form of gratitude, a symbol of wishing for success and prayer for pilgrims to be granted their wishes. 
so it is believed that the place still keeps the magic of those figures radiating through the aura that surrounds the place. The places of such magic figures can be in the form of temples, and grave sites or shrines ([22]-109).

The grave of Prince Samudro has a mystical aura manifested by the mystical belief of the powerful figures buried there. Items like the mosquito nets and umbrellas that cover the tomb are therefore accorded a special cleansing ritual, hence the Lorop Slambu event. Outside the tomb is a rare nagasari tree which is a rare tree that does not exist elsewhere and the banyon tree that adds to the atmosphere more mystical impression. Stories about the place narrated by the caretaker to pilgrims, tourists and other visitors are abound with tales of a figure also buried at Prince Samudro's, called petilason as a kind of mystical figure of magical powers.

The following photos show scenes the pilgrims witness at the Tomb of Prince Samudro that reinforce their belief of magical and sacred power, thus raising the trust of pilgrims on the power of Prince Samudro's character.

The Larap Slambu event, or the washing of the slambu (tomb cloth) of Prince Samudro's tomb has become a cultural and tourist attraction that the local government puts in effort as a way of preserving Javanese culture and introducing good values through wayang performances. But this ritual is also inseparable from the ritual of Ngalap Berkah which is the act of asking for blessings from dead figures believed to have possessed powerful mystical powers, in this case Prince Samudro. Rituals like the Nglarap Slambu ritual is held to coincide with Friday night or Kliwon. This is intended to attract more pilgrims who want to purely perform pilgrimage rituals to meet the needs of their spiritual and religious urges given that Friday is an Islamic weekly holyday giving the pilgrims a comforting spiritual feeling, on the other hand, Friday is the start of a weekend so it is intended to also attract other visitors, tourists and thrill seekers who take the event as a leisure activity to get a break from everyday life and engage in other leisurely activities like travel, drinking, clubbing and wild sex escapades with strangers under the guise that it is a sex ritual that is complementary to and part of the pilgrimage pattern of the rituals. But there is a belief among many pilgrims that the sexual intercourse is part of the complement to the rituals of the pilgrimage. So the motivation of the visitors to the tomb of Prince Samdro is religious, spiritual, cultural and historical, on the other hand, it is for leisure, curiosity, thrill and purely fun especially with the popular media reports of Mount Kemukus being a place of sex rituals arouse the interest of many curios people who want to experience and participate in 'sex rituals'. 

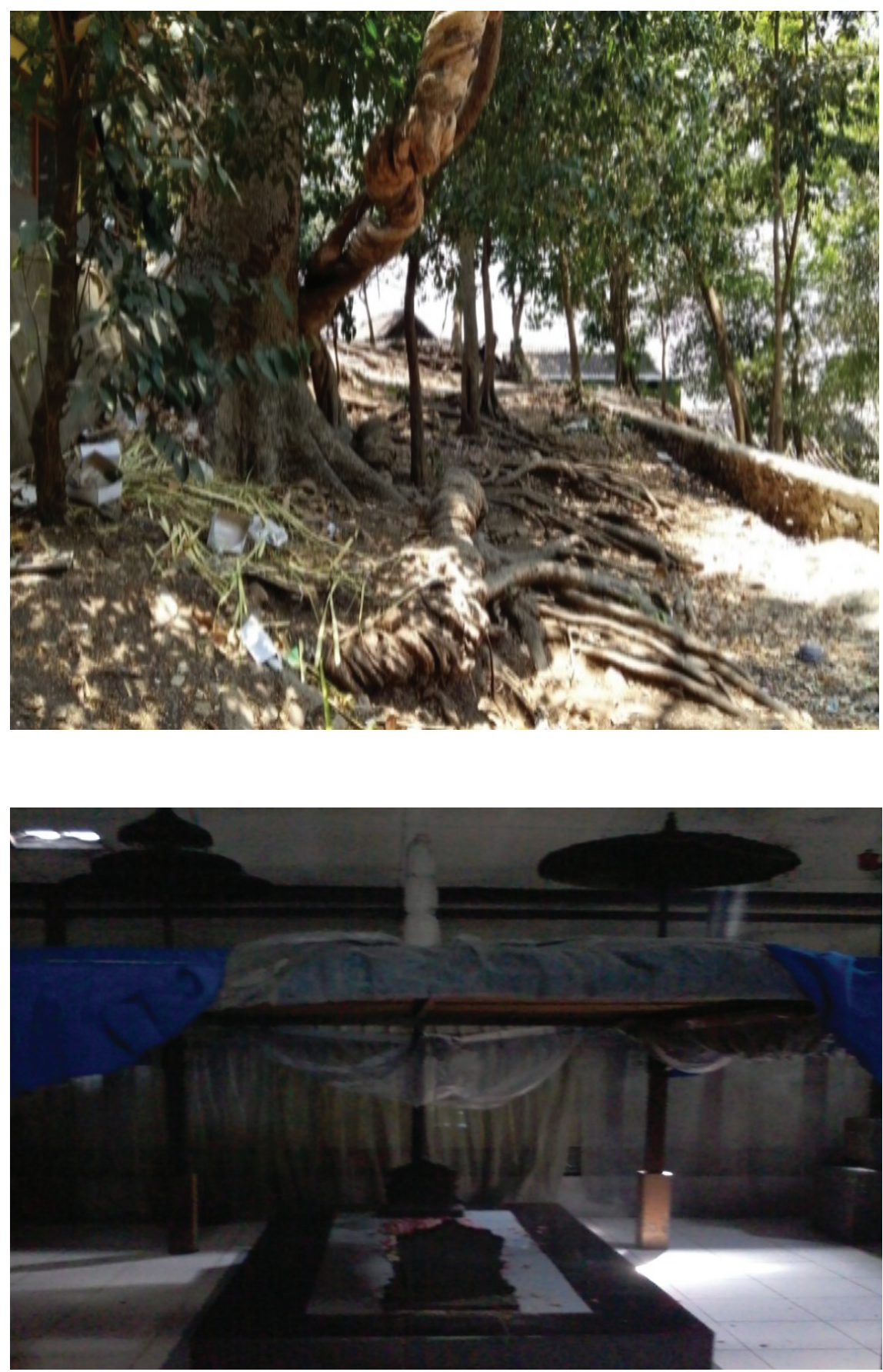

Figure 11

In fact, the ritual of Mount Kemukus, became famous because one of the rituals of the pilgrimage was the existence of a sexual relationship with one who is not a legitimate partner in marriage, but must be a permanent partner with whom they are to perform sexual intercourse after every 35 days seven times. This belief and behavior pattern, makes the Tomb of Prince Samudro a magnet of sex tourists, enthusiasts and pilgrims to indulge in the rituals, many with the belief that the ritual brings blessings. 
The implementation of this ritual arises out of religious beliefs that are varied and loaded with mythical values. So there arises irrational behavior from the myth, but behind the same myth, the economy and incomes of the locals and the local government through the visits of pilgrims and foreign tourists.

A tourist spot certainly has an impact on the surrounding environment. This is said by Gee (1989) in his book, The Travel Industry, saying that 'as tourism grows and travelers increase, so does the potential for both positive and negative impacts'. (Gee says there is a positive or negative impact or influence due to tourism development and increased tourist arrivals). The impacts of the impacts of tourism will certainly affect the surrounding environment and according to Lerner (1977) cited by Allister Mathieson and Geoffrey Wall (1982) in any 'Tourism: Social, Economic, and Environmental Impacts' within the environment. Lerner writes: "Environment now includes not just land, water and air but also encompasses to people, their creation, and the social, economic, and cultural conditions that affect their lives." So that is affected by the positive and negative is according to what is said by Lerner is society, environment, economic and social.

People in the environment of a tourist attraction are very important in the life of a tourist attraction because they have a culture that can become a tourist attraction, community support for tourist attractions in form of basic necessities for places of tourism, adequate manpower for the manager of the attractions, the survival of tourism objects and the satisfaction of the people who need jobs which make people's lives better. This happens to the community around the tomb of Prince Samudro by way of maintaining the ritual of pilgrimage, formed based on myth and because the myth setting was in their geographical area, the area become an economic commodity that provides income to the in the tourism sector of through ticket sales and able to provide Economic improvement for people around the tourist sites.

\section{Conclusion}

The larap slambu ritual is based on myths to preserve the existence of these rituals for many years, since the function of these myths awakens humans to magical powers, the myth gives current guarantees, for example there is a worldly life for the better, through rituals at the pilgrimage and it can be noted that a myth is similar to function as science and philosophy to the modern mind, that myth gives knowledge of the world, only humans have a very high understanding to make sense of myths. What powers larap slambu Is still ambiguous because it has double meaning or the message 
conveyed behind the myth has certain interests, depending on the conditions or events that occur as the myths develop.

The communication aspect of the larap slambu event generated a tourist industry that still occupies many people in Indonesia as many wish to visit places that are considered to have magical powers to ask for blessings so that what is desired is answered. The process of larap slambu is meant to seek blessings through particular flowers of kanthil mixed in bathing water. The communication pattern in the rituals of Ngalap Berkah consists of symbols in form of actions, interaction, Flowers, water and incense. In addition, sexual intercourse is taken as a condition of complementary ritual sex which is merely a symbol, which develops based on belief in interpreting the meaning of the symbol. The meaning of success in performing the slamaton ritual is to take flowers found in the tomb believed to bring blessings. The communication component of this pilgrimage is present a multitude of communication types including non-verbal, symbols, signals with multiple genres. This mixture facilitates interaction, education and business at the pilgrimage as well as offering a glimpse into Javanese ancient culture, religion and history.

The interaction pattern facilitated and accomplished cooperation and the development and sustenance of the pilgrimage and its rituals mainly propagated by from word of mouth using the native Javanese language and the existence of the symbols of success through the slametan rituals by those who have 'succeeded' in life, hence powering more belief in the greatness of the Tomb of Prince Samudro.

Much as it is important to attract tourists to this event, it is also equally important to keep it positive by propagating a more positive understanding of the event and improving it as good tourist destination rich in culture and memorable experiences for all kinds of tourists, not only to be known as a place of bizarre spiritual practices or just a sex tourism destination, It is certain more than that.

The Indonesian central government, in this case the Ministry of Tourism, should devise a standard of special tourism packages for pilgrimage tours specifically for this venue, the destination should be one of those historical elements of the country reflected in the countries major destinations for its uniqueness. More to that, there is a need to improve the facilities, infrastructure and other vital services at the site to suit the convenient movement and stay of tourists at the site and in the surrounding communities. This can be coupled with involving all relevant elements in the tourism business to be sensitized on tourism consciousness and management in this case using a systematic management and tourist attraction management by involving all elements of society. Government may also as classify pilgrimage tours that are intended 
for religious purposes or interests or spiritual purposes, so that there are standards in accordance with these provisions, so as to improve the competitiveness of tourism for cultural attractions or religious tourism to the places considered religious.

Suggestions for Regional Government in this case the Central Java Province and Regency in cooperation with Sragen Tourism Office, and village apparatus of the Sub District, and Community (RT/RW and Community Leaders):

1. Larap slambu is one of the main attraction, so it must be preserved and maintained in its meaning in accordance with both the prevailing local rules and norms and the native Javanese norms, meaning that slambu work can be used as a medium of tourist attraction other than just pilgrimage tours.

2. Eliminate perceptions about the sex rituals of or as a place of sex tourism, because this is a magnet or a high attraction for pilgrims or tourists to visit the Tomb of Prince Samudro, so this undermines strategies to attract visitors interested in ritual Pilgrimage to fulfill religious and spiritual needs, by developing other alternatives in the form of local people's creativity by displaying local culture through certain events packaged in collaboration with other interconnected attractions and can provide the experience for tourists (secondary attraction), so that income especially from tourism business actors and the Tourism Office of Sragen Regency remains stable.

3. In the future tourism development should the surrounding community members involved. The existence of this tourism activity provides a good economic impact for the community and the government on one side, so that the construction of access and facilities around 'Kemukus', for example through lighting with the installation of lights in every corner that can lead to immoral acts, such as mushola, parking, clean water, Facilities such as restaurants or restaurant and lodging should be standardized as tourist attractions

4. On the other hand the existence of this destination has always been a disagreement on morality and religion which views all matters relating to the mystique, so that the Society must be informed through the real, true history of the government by disseminating information through social media or traditional media such as pamphlets and through Word or word of mouth through public figures, Travel agents and pilgrims themselves as agents who convey or build myths about the character 'Prince Samudro' is positive.

5. Prostitution is a thing to be avoided, so the Government must successfully close the localization of illegal stalls to be used for prostitution. As well as business 
permit regulations should be more strictly regulated and evaluation to the field by the Local Government Agencies and Security Apparatus.

6. Build awareness of migrant communities to be more loving and have a sense of belonging to the environment, thus helping to improve the image of Prince Samudro's grave through availing economic benefits from tourism to them;

7. Community empowerment through micro small business to prostitutes who are settled in Pendem Village, which has been done now with goats for the purpose of searching livelihood through goat breeding and sewing skills, but needs to be evaluated and mapping study for community empowerment for the long term Short and long term, because the ultimate goal is to increase the level of economy and prosperity of the surrounding community. Empower the local community people to produce souvenirs or crafts for the memories after visiting the tomb, however, it is important to foster continuous improvement of the living standards of people from upstream people to downstream people, from the production process to marketing.

\section{References}

[1] Barker, Chris, 2009. Cultural Studies teori dan Praktek. Yogyakarta: Kreasi Wacana.

[2] Bungin, Burhan, 2009. Penelition Kualitatif. Jakarta: Kencana Prenada Media Group.

[3] Carey, James W. 1992. Communication as Culture Essay on Media and Society. New York: Routledge.

[4] Clifford, James. 1988. "The Predicament of Culture: Twentieth-Century Ethnography, Literature, and Art". Cambridge, Massachusetts: Harvard University Press.

[5] Devito, Joseph. A. 1997. Komunikasi Antor Manusia, kuliah dasar edisi ke-5 penerjemah: Agus Maulana, Jakarta, professional Books.

[6] Geertz, Clifford. 1973. The Interpretation of Cultures. New York: Basc Books.

[7] Geertz, Clifford. 1981. The Religion of Java, London: The Free Press law of Glencoe.

[8] Hammad, Ibnu. 2006. Communication as Discourse. Makalah. Jakarta

[9] Hammad, Ibnu. 1999. Media Massa dan Konstruksi Realitos. Jurnal Pantau. Edisi 6, Jakarta: ISAI

[10] Hymes, Dell, 1996, Ethnography, Linguistic, Narrative, Inequality, Taylor \& Francis, Inc, 1900 Forst Road, Suite 101, Bristol, PA 19007

[11] Ibrahim, Abd Syukur. 1994. Panduan Penelitian Etnografi Komunikasi. Surabaya: Usaha Nasional Indonesia. 
[12] James P. Spradley. 1997. Metode Etnografi. Terjemahan Misbah Zulfa Elizabeth. Yogyakarta: Tiara Wacana.

[13] Koentjaraningrat. 1964. "Tokoh-Tokoh Antropologi". Jakarta: PT Penerbitan Universitas Indonesia.

[14] Koentjaraningrat. 1990. "Sejarah Teori Antropologi II". Jakarta: Penerbit UI-Press.

[15] Koentjaraningrat. 1996. "Pengantar Antropologi I". Jakarta: Penerbit Rekatama Cipta.

[16] Koentjaraningrat. 1996, Kebudayaan Mentalitas dan Pembangunan, PT. Gramedia Pustaka Utama, Jakarta.

[17] Kuswarno Engkus. 2008. Etnografi Komunikasi suatu Pengantar dan Contoh Penelitiannya. Widya Padjadjaran. Bandung

[18] Littlejohn, S. W. 1996. Theories of Human Communication ( $5^{\text {th }}$ ed.). Thomson Wadsworth. Belmont, CA, USA

[19] Littlejohn, S.W. and K.A. Foss. 2005. Theories of Human Communication ( $8^{\text {th }}$ ed.). Thomson Wadsworth. Belmont, CA, USA

[20] Littlejohn, Stephen W. 2005. Theories of Human Communication. Belmond: Wadsworth Publishing Company.

[21] Littlejohn, Stephen W. A. Foss, Karen 2010. Teori Komunikasi. Jakarta: Salemba Humanika

[22] MH Yana, 2012, Falsafah Dan Pandangan Hidup Orang Jawa, Bintang Cemerlang, Yogyakarta.

[23] Mulyana, Deddy. 2002. Metode Penelitian Kualitatif: Paradigma Baru Ilmu Komunikasi dan Ilmu Lainnya. Bandung: PT. Remaja Rosdakarya.

[24] Mulyana, Deddy. 2005. Komunikasi Efektif. Bandung: PT. Remaja Rosdakarya.

[25] Mulyana, Deddy. 2007. Ilmu Komunikasi Suatu Pengantar. Bandung. PT. Remaja Rosdakarya.

[26] Mulyana, Deddy dan Rahkmat, Jalaluddin (ed). 2006. Komunikasi Antarbudaya,. Panduan berkomunikasi dengan orang-orang berbeda budaya. Bandung. PT. Remaja Rosdakarya.

[27] Mulyana, Deddy \& Solatun, 2008, Metode Penelitian Komunikasi: Contoh-Contoh Penelitian Kualitatif Dengan Pendekatan Praktis, Bandung: Remaja Rosda Karya,

[28] Muriel Saville-Troike, 1982. The Ethnography of Communication: An Introduction. Southampton: Basil Blackwell Publisher Limited.

[29] Pals, Daniel L. 2001. "Seven Theories of Religion: Dari Animisme E.B. Tylor, Materialisme Karl Marx, hingga Antropologi Budaya Clifford Geertz". Yogyakarta: Penerbit Qalam. 
[30] Poerwandari, Kristi. 2001. Pendekaton Kualitatif untuk Penelition Perilaku Manusia. Jakarta: Lembaga Pengembangan Sarana Pengukuran dan Pendidikan Psikologi (LPSP3) UI.

[31] Purwasito, Andrik. 2003. Komunikasi Multikultural. Surakarta: Muhammadiyah University Press.

[32] Rothenbuhler, Eric W. 1998. Ritual Communication: From Everyday Conversation to Mediated Ceremony. Thousand Oaks. SAGE Publications.

[33] Rothenbuhler, Eric W. dan Mihai Coman. 2005. The Promise Of Media Anthropology, dalam Media Anthropology. Editor. Eric W. Rothenbuhler dan Mihai Coman. Thousand Oaks. SAGE Publications.

[34] Spradley, James. P. 1980. "Participant Observation". Orlando, Florida: Macalester College.

[35] Spradley, James. P. 2007. "Metode Etnografi." Diterjemahkan oleh Misbah

[36] Sumiarni, Endang, 1999, Seks dan Ritual di Gunung Kemukus, Pusat Pendidikan dan Penelitian Universitas Gadjah Mada, Yogyakarta

[37] Zoetmulder. 1990. Manunggaling Kawula Gusty. Pantheisme dan Monisme dalam Sastra Suluk Jawa. Suatu Studi Filsafot. Jakarta: Gramedia.

\section{Internet Source}

[38] Pemerintah Kabupaten Sragen. Dinas Pariwisata Kebudayaan dan Olahraga di Obyek Wisata Ziarah Pangeran Samudro Di Gunung Kemukus Antara Keyakinan dan Mitos Sragen tanpa penerbit.

[39] TRIBUNNEWS.COM, JAKARTA - Tentang Kisah Ritual Seks Aneh di Gunung Kemukus atau dengan nama "Gunung Seks" oleh Patrick Abboud, jurnalis asing dari program Dateline SBS Australia.

[40] Metronews.com tentang Ritual di Gunung Kemukus, Sragen, oleh MI/Ahmad Safuan

\section{Research Result}

[41] Tony Harsono, 2004, Pelayanan Keamanan Terhadap Peziarah Di Gunung Kemukus. Thesis. Universitas Indonesia

[42] Sugimin, 2004, Persepsi Masyarakat Terhadap Makam Pangeran Samudera Di Desa Pendem Kecamatan Sumberlawang Kabupaten Sragen, Skripsi, Institut Keguruan dan Ilmu Pendidikan Veteran Semarang 
[43] Bambang Wiratsongko, 2008, Perilaku wisata ritual gunung kemukus (Studi Deskriptif perilaku ritual wisatawan obyek wisata makam Pangeran Samodra: Gunung Kemukus" di Sumber Lawang, Sragen, Jawa Tengah). Thesis, Surakarta

[44] Moh Soehadha, 2013, Komodifikasi Asketisme Islam Jawa; Ekspansi Pasar Pariwisata dan Prostitusi di Balik Tradisi Ziarah di Gunung Kemukus. Jurnal Multikultural \& Multireligius Vol 12

[45] Adelaide Worcester, 2002, Pelacuran dalam Konteks Budaya, FISIP Universitas Muhammdiyah Malang bekerjasama dengan Acicis Study Indonesia Program

[46] Mohammad Husein Hutagalung, 2013, Studi Eksistensi Aktifitas Ziarah Dan Prostitusi di Kawasan Religi Gunung Kemukus, Purwodadi, Jawa Tengah.

[47] Orlando De Guzman, 2006, Apakah ada Hubungan Antara G3oS PKI Dan Munculnya Mitos Pangeran Samudra

[48] Rahardi FX, 2008, Ritual Gunung Kemukus, Lamahera, Yogyakarta. 